\title{
MEMPREDIKSI PENGARUH KONTRIBUSI KEMAMPUAN PERENCANAAN KARIER TERHADAP MOTIVASI BELAJAR PESERTA DIDIK SEKOLAH MENENGAH KEJURUAN
}

\author{
Yurike Kinanthy Karamoy ${ }^{1}$, Endarta Murti Basuki ${ }^{2}$ \\ Prodi Bimbingan dan Konseling,FKIP,Universitas Islam Jember,Indonesia \\ SMK Negeri 2 Jember, Indonesia \\ yurikekaramoy@gmail.com¹, endarta19@gmail.com,
}

\begin{abstract}
ABSTRAK
Kompetensi perencanaan karier menjadi fokus pelayanan bimbingan dan konseling pada Sekolah Menengah Kejuruan (SMK). Kompetensi perencanaan karier dapat berkembang dipengaruhi oleh motivasi. Seberapa besar kontibusi dari motivasi belajar terhadap kompetensi perencanaan karier peserta didik menjadi fokus pada penelitian ini. Tujuan penelitian ini adalah untuk mengklarifikasi hasil temuan terdahulu berkaitan dengan pengaruh kemampuan perencanaan karier terdapat motivasi belajar peserta didik yang ditinjau dari faktor budaya. Penelitian saat ini menerapkan pendekatan kuantitatif melalui survei desain cross-sectional. Populasi penelitian ini adalah peserta didik SMK di Kabupaten Jember. Sampel penelitian ini berjumlah 346 orang. Teknik pengambilan sampel yang digunakan adalah crosssectional sampling. Teknik pengumpulan data menggunakan instrumen skala psikologis Kemampuan Perencanaan Karier (KPK) dan Skala Motivasi Belajar (SMB). Analisis data menggunakan teknik regresi linier dengan bantuan aplikasi pengolah data statistik IBM SPSS Statistics. Hasil penelitian menunjukan bahwa motivasi belajar memberikan kontribusi positif terhadap kemampuan perencaanaan karier peserta didik SMK. Layanan konseling karier sangat dibutuhkan untuk menyamakan persepsi anak dan orang tua terhadap pilihan karier anak.
\end{abstract}

Kata Kunci: Kemampuan Perencanaan Karier; Motivasi Belajar; Layanan Konseling Karier

\begin{abstract}
Career planning competencies are the focus of guidance and counseling services at Vocational High Schools (SMK). Career planning competence can develop influenced by motivation. How big is the contribution of learning motivation to students' career planning competencies is the focus of this research. The purpose of this study was to clarify the results of previous findings related to the influence of career planning abilities on students' learning motivation in terms of cultural factors. The current study applies a quantitative approach through a cross-sectional survey design. The population of this research is SMK students in Jember Regency. The sample of this study amounted to 346 people. The sampling technique used is cross-sectional sampling. Data collection techniques used the psychological scale of Career Planning Ability (KPK) and Learning Motivation Scale (SMB). Data analysis used linear regression technique with the help of statistical data processing application IBM SPSS Statistics. The results showed that learning motivation gave a positive contribution to the career planning skills of vocational students. Career counseling services are urgently needed to equalize the perception of children and parents on children's career choices.
\end{abstract}

Keywords: Career Planning Skils; Learning Motivations; Career Counseling Services

Dipublikasikan Oleh :

UPT Publikasi dan Pengelolaan Jurnal

Universitas Islam Kalimantan Muhammad Arsyad Al-Banjari Banjarmasin 


\section{PENDAHULUAN}

Seluruh aktifitas individu didorong oleh keinginan mencapai tujuan tertentu. Dorongan tersebut muncul dari dalam diri dan dapat juga muncul dari faktor luar diri (Emda, 2018). Penting untuk konselor sekolah memahami motivasi peserta didik di sekolah(Septianti \& Afiani, 2020). Motivasi peserta didik dapat berupa karier, prestasi atau tujuan tertentu lainnya.Lebih lanjut motivasi tersebut akan mempengaruhi tujuan peserta didik dalam melakukankegiatan belajar di sekolah.

Berdasarkan hasil temuan dari (Habibi, 2021) menunjukan bahwa peserta didik yang memiliki motivasi tinggi untuk mencapai karier tertentu, mereka lebih termotivasi untuk belajar di sekolah. Namun bereda dengan temuan dari (Sulusyawati \& Melati, 2019) yang menunjukan bahwa perencanaan karier sering kali dipengaruhi oleh keputusan orang tua, hal tersebut berdampak pada rendahnya motivas belajar dankepercayaan diri untuk menentukan keputusan. Lebih lanjut tujuan penelitian ini yaitu mengklarifikasi hasil temuan terdahulu berkaitan dengan pengaruh kemampuan perencanaan karier terdapat motivasi belajar peserta didik yang ditinjau dari faktor budaya.

Program bimbingan dan konseling abat 21 , berfokus pada pengembangan diri terutama pada bidang akademik, karier, pribadi-sosial dan spiritual (Siregar, 2020). Perencanaan kariermerupakan suatu proses individuuntuk mementukan pilihan atau aktifitas tertentu untuk mencapai tujuan karier yang diinginkan (Atmaja, 2014; Massie, 2015). Terdapat faktor-faktor yang mempengaruhi perencanaan karier peserta didik antara lain yaitu; kelas sosial, orang tua dan teman sebaya,sekolah, gender serta etnik(Patel et al., 2008). Berdasarkan faktor tersebut orang tua merupakan faktor yang paling mempengaruhi peserta didik dalam perencaan karier (Amsir \& Arifyanto, 2021; Sulusyawati \& Melati, 2019). Aminurrohim et al.(2014) yang menyatakan bahwa kondisi keluarga merupakan faktor penghambat perencanaan karier peserta didik. Lebih lanjut Orang tuaselalu menjadi pertimbangan pertama pada pesera didik untuk pengambilan keputusan.

Pola pengasuhan orang tua telah membentuk kepribadian peserta didik untuk mengambil keputusan (Sulusyawati \& Melati, 2019). Selain itu karier orang tua dapat juga menjadi panutan atau motivasi mendapatkan karier yang lebih baik (Komara, 2016).Untuk mencapai posisi karier tertentu peserta didik dihadapkan dengan barbagai keadaan antara lain: kelas sosial, orang tua dan teman sebaya,sekolah, gender serta etnik. Kondisi tersebut dapat menjadi munculnya motivasi untuk memperbaiki keadaan atau malah sebaliknya (Aminurrohim et al., 2014). Lebih lanjut merekaharus merumuskantujuan spesifikdan memunculkan motivasi dalam melakukankegiatan belajar sebagai cara mencapai tujuan.

Semakin spesifik tujuan peserta didik dapat mempengaruhi tingkat motivasi belajar pesertadidik. Motivasi merupakan pendorong untuk mencapai tujuan tertentu yangdapat menjadi kekuatan dalam mengembangkan potensi secara maksimal, melalui proses belajar peserta didik (Nugraha et al., 2021; Supriadi, 2019).Peserta didik dengan motivasi belajar rendah dapat menjadi penghambat pencapaian tujuan, meskipun peserta didik memiliki potensi untuk berkembang (Nazirwan, 2020). Lebih lanjut konselor sekolah perlu untuk membantu peserta didik dengan motivasi belajar rendah untuk meningkatkan motivasinya untuk semangat belajar dan mencapi tujuan tertentu.

Peserta didik yang memiliki motivasi belajar tinggi dicirikan dengan; mampu mengolah informasi secara mendalam, mengalami lebih sedikit masalah-masalah manajemen, memiliki sikap positif tehadap sekolah(Achyanadia, 2013; Idola et al., 2017; Saptono, 2016). Sardiman (2001) menambahkan ciri-ciri peserta didik memiliki motivasi belajar tinggi atara lain; tekun dalam mengerjakan tugas, meiliki pendirian yang kuat, lebih siap menghadapi masalah dan memiliki kemampuan mencari solusi terbaik. Lebih lanjut peserta didik dengan motivasi belajar tinggi lebih memiliki kesiapan untuk bertahan dalam setiap kesulitan ketika melakukan proses belajar.

Peserta didik diharapkan telah mengembangkan kemampuan perencanaan karier, dengan demikian mereka akan memiliki motivasi belajar di sekolah. Namun berdasarkan temuan terdahulu menunjukan bahwa perencanaan karier dipengaruhi oleh banyak fakor (Sulusyawati \& Melati, 2019) sedangkan motivasi belajar menjadi prediktor peserta didik berhasil dalam menempati posisi karier tertentu (Habibi, 2021). Penting untuk mengetahui kontribusi kemampuan perencanaan kairer terhadap motivasi belajar peserta didik. Lebih lanjut hasil penelitian ini dapat menjadi dasar dari pelaksanaan layanan bimbingan dan konseling untuk meningkatkan kemampuan perencanaan karier peserta didik. Hipotesis pada penelitian ini adalah Kemampuan perencanaan karier peserta didik secara signifikan berkontribusi terhadap motivasi belajar peserta didik. 
Yurike Kinanthy Karamoy, Endarta Murti Basuki Jurnal Bimbingan dan Konseling Ar-Rahman

Volume 7, Nomor 2, Tahun 2021

e-ISSN 2477-6300

\section{METODE}

Penelitian ini merupakan penelitian kuantitatif melalui desain survei cross-sectional. Peneliti berkolaborasi dengan sejumlah kepala sekolah di Kabupaten Jember, Indonesia.Mereka menugaskan guru BK di sekolahnya untuk membagikan link skala penelitian kepada siswanya.

Hipotesis penelitian yaitu terdapat kontribusi positif kemampuan perencanaan karier pesertadidik terhadap motivasi belajar peserta didik SMK. Teknik analisis data menggunkan analisis regresi linier dengan bantuan IBM SPPS 20 for Windos untuk menguji hipotesis penelitian.

Populasi penelitian ini adalah peserta didik SMK di Kabupaten Jember, dengan sampel sebanyak 346 orang di Kabupaten Jember, Indonesia sebagai sampel. Dengan rincian sebagai berikut laki-laki 112 perempuan 224.

Penelitian ini menggunakan dua skala psikologis. Instrumen pertama adalah Skala Kemampuan Perencanaan Karier (KPK) yang di kembangkan oleh Prahmawati, (2018) untuk mengukur kemampuan perencanaan karier yang dilaporkan sendiri. Skala ini terdiri dari 32item yang dilengkapi dengan skala Likert lima poin, mulai dari: SS : Sangat Setuju; TS : Tidak Setuju; S : Setuju;dan STS : Sangat Tidak Setuju. Contoh item "Saya mengetahui bakat yang ada dalam diri saya."dan "Saya merasa tidak perlu membuat rencana dalam mencapai cita-cita." Hasil uji reliabilitas menggunakan Cronbach's = 0.91 (Prahmawati, 2018). Berdasarkan hasil uji validitas dan reliabilitas skala Kemampuan Perencanaan Karier (KPK) dapat dikategorikan sangat baik. Namun hasil uji Reliabilitas pada penelitian ini dengan 32 item menunjukan skorCronbach's $=0,541$. Selanjutnya dilakukan uji Validitas dengan menggunakan Item Response Theory (IRT) dengan terpaksa kami menghapus item nomor: 6, 9, 19, 21,26 dan 28. Hasil uji Reliabilitas meningkat menjadi Cronbach's $=0,608$, atau dapat bahwa instrumen dapat digunakan karena terkategori baik. Lebih lanjut penelitian ini menggunakan 26 item skala psikologis Kemampuan Perencanaan Karier (KPK).

Instrumen kedua adalah Skala Motivasi Belajar (SMB) yang di kembangkan oleh Anugraheni et al., (2019) untuk mengukur motivasi belajar peserta didik yang dilaporkan sendiri. Skala ini terdiri dari dua puluh empat pertanyaan yang dilengkapi dengan skala Likert lima poin, mulai dari: SS : Sangat Setuju; TS : Tidak Setuju; S : Setuju;dan STS : Sangat Tidak Setuju. Contoh item "Menurut saya belajar itu penting." dan "Saya menunda belajar sampai diingatkan." Hasil uji reliabilitas menggunakan Cronbach's $=0.89$ (Anugraheni et al., 2019). Berdasarkan hasil uji validitas dan reliabilitas skala motivasi belajar (SMB) dapat dikategorikan sangat baik. Lebih lanjut hasil uji Reliabilitas instrumen pada penelitian ini menunjukan Cronbach's $=0.629$, dapat diartikan bahwa Skala Motivasi Belajar berkategori baik.

\section{HASIL DAN PEMBAHASAN}

Hasil

Analisis deskriptif kuantitatif menunjukan bahwakemampuan perencanaan karier dan motivasi belajar peserta didik dapat dilihat pada Tabel 1 .

Tabel 1. Hasil Analisis Deskripstif

\begin{tabular}{lcc}
\hline \multicolumn{1}{c}{ Variabel } & Rata-Rata & Simpangan Baku \\
\hline Kemampuan Perencanaan Karier & 68.15 & 8.617 \\
Motivasi Belajar & 59.29 & 8.381 \\
Kemampuan Perencanaan Karier (Laki-laki) & 68.27 & 9.834 \\
Kemampuan Perencanaan Karier (Perempuan) & 68.09 & 7.991 \\
Motivasi Belajar (Laki-laki) & 55.66 & 12.561 \\
Motivasi Belajar (Perempuan) & 61.03 & 4.414 \\
\hline
\end{tabular}

Hasil analisis deskriptif menunjukan rata-rata kemampuan perencanaan karier peserta didik SMK di Kabupaten Jember sebesar ( $\mathrm{M}=$ 68.2; $\mathrm{SD}=8.62)$ dan rata-rata motivasi belajar sebesar $(M=59.3 ; S D=8.38)$. Selanjutnya ratarata kemampuan perencanaan karier pada peserta didik laki-laki $(\mathrm{M}=68.3 ; \mathrm{SD}=9.83)$ lebih tinggi dari pada perempuan $(\mathrm{M}=68.1$; $\mathrm{SD}=$ 7.99). Terakhir rata-rata peserta didik lakilaki $(\mathrm{M}=55.7 ; \mathrm{SD}=12.56)$ lebih rendah dari pada peserta didik perempuan $(\mathrm{M}=61.0$; $\mathrm{SD}=$ 4.41). Lebih lanjut data telah diuji analisis prasyarat untuk menguji hipotesis penelitian.

Dipublikasikan Oleh :

UPT Publikasi dan Pengelolaan Jurnal

Universitas Islam Kalimantan Muhammad Arsyad Al-Banjari Banjarmasin 
Yurike Kinanthy Karamoy, Endarta Murti Basuki

Jurnal Bimbingan dan Konseling Ar-Rahman

Volume 7, Nomor 2, Tahun 2021

e-ISSN 2477-6300

Tabel 2. Model Summary

\begin{tabular}{|c|c|c|c|c|c|c|c|c|c|}
\hline \multirow[b]{2}{*}{ Model } & \multirow[b]{2}{*}{$\mathrm{R}$} & \multirow[b]{2}{*}{ R Square } & \multirow[b]{2}{*}{$\begin{array}{l}\text { Adjusted R } \\
\text { Square }\end{array}$} & \multirow[b]{2}{*}{$\begin{array}{l}\text { Std. Error of } \\
\text { the Estimate }\end{array}$} & \multicolumn{5}{|c|}{ Change Statistics } \\
\hline & & & & & $\begin{array}{l}\text { R Square } \\
\text { Change }\end{array}$ & F Change & df1 & df2 & $\begin{array}{c}\text { Sig. F } \\
\text { Change }\end{array}$ \\
\hline 1 & $0,313^{\mathrm{a}}$ & 0,098 & 0,095 & 8,19650 & 0,098 & 37,332 & 1 & 344 & 0,000 \\
\hline
\end{tabular}

Tabel 3.Coefficients

\begin{tabular}{llrrrr}
\hline & \multicolumn{2}{c}{$\begin{array}{l}\text { Unstandardized } \\
\text { Coefficients }\end{array}$} & $\begin{array}{c}\text { Standardized } \\
\text { Coefficients }\end{array}$ & & t \\
\cline { 2 - 5 } & \multicolumn{1}{c}{ B } & Std. Error & Beta & & P \\
\hline (Constant) & 87,226 & 3,153 & & 27,668 & 0,000 \\
Motivasi Belajar & $-0,322$ & 0,053 & $-0,313$ & $-6,110$ & 0,000 \\
\hline
\end{tabular}

a. Dependent Variable: Kemampuan Perencanaan Karier

\begin{abstract}
Melanjutkan analisis, model regresi linier berganda diterapkan untuk mengidentifikasi hubungan antara kemampuan perencanaan karierdan motivasi belajarpeserta didik SMK di Kabupaten Jember. Hipotesis diperiksa dan dinyatakan layak untuk ditindaklanjuti dengan analisis regresi linier berganda.Hasil regresi linier berganda (Tabel 3) menegaskan bahwa motivasi belajar adalah prediktor dari kemampuan perencanaan karier. Korelasi varians sebesar $31,3 \%$ dengan F $(1,344)$ $=8,196$ dan $\mathrm{p}=0,000$. Sementara itu, motivasi belajar memberikan kontribusi yang signifikan terhadap model $(\mathrm{B}=-0.32$ dan $\mathrm{p}=0.000)$.
\end{abstract}

\section{Pembahasan}

Kemampuan perencanaan karier merupakan kesanggupan dari peserta didikuntuk merencanakan pekerjaan yang mengarah pada dunia kerja dan masa depannya sendiri.Kemampuan perencanaan karier dipengaruhi oleh beberapa faktor seperti, orang tua, lingkungan, dan motvasi instrinsik (Rosyadi, 2017; Susanti \& Mulyoto, 2020). Hasil penelitian mendukung hasil penelitian terdahulu yang menyatakan bahwa faktor internal (motivasi instrinsik), merupakan prediktor kuat peserta didik memiliki kemampuan perencanaan karier (Habibi, 2021; Suryani et al., 2019). Lebih lanjut motivasi belajar merupakan dorongan yang muncul dari dalam diri peserta didik untuk mendapatkan informasi, pengetahuan dan keterampilan sebagai persiapan memasukui pasar kerja dan dunia kerja.

Peserta didik dengan motivasi belajar tinggi lebih memiliki tujuan spesifik seperti, sungguh dalam memahami teori di sekolah, mempunyai target tertentu yang akan dicapai, dan mempersiapkan diri untuk mencapai tujuan (Suryani et al., 2019). Layanan konseling individu atau kelompok penting untuk membantu perserta didik meningkatkan motivasi belajar.
Layanan konseling individu penting dilaksanakan untuk mendukung kesiapan karier peserta didik (Gusta, 2020). Namun untuk mengakomudir peserta didik SMK dengan jumlah yang banyak layanan konseling individu kurang efektif. Layanan konseling kelompok atau pelatihan kerja On The Job Trening lebih bermanfaat (Rosyadi, 2017; Susanti \& Mulyoto, 2020).

On The Job Trening merupakanprogramyang disusun untuk memberikan kesempatan peserta didik belajar secara langsung dunia usaha atau industri untuk memberikan pengalaman dan kemampuan praktik di dunia kerja nyata (Susanti \& Mulyoto, 2020). Berdasarkan hasil penelitian terdahulu program On The Job Trening secara signifikan berpengaruh pada peningkatan motivasi dan kesiapan memasuki dunia kerja (Rosyadi, 2017; Susanti \& Mulyoto, 2020).Lebih lanjut banyak program layanan karier yang dapat dimanfaatkan untuk meningkatkan motivasi peserta didik.

Terakhir lembaga penyedia layanan konseling diharapkan menyusun program konseling keluarga untuk mempertemukan anak dan orang tua dengan tujuan menyamakan harapan dan keinginan karier peserta didik (Sulusyawati \& Melati, 2019).Keselarasan harapan anak dan orang tua terhadap kesiapan kerja peserta didik merupakan kolaborasi yang diharapkan. Anak menjadi nyaman melaksanakan aktifitas belajar dan praktik belajar, begitu juga orang tua memahami keingian anak dan memberikan fasilitas (Syafaruddin et al., 2019). Lebih lanjut layanan konseling keluarga penting untuk membantu meingkatkan motivasi belajar dan kesiapan karier peserta didik.

\section{Keterbatasan}

Hasil penelitian ini telah mengklarifikasi hasil penelitian terdahulu. 
Yurike Kinanthy Karamoy, Endarta Murti Basuki

Jurnal Bimbingan dan Konseling Ar-Rahman

Volume 7, Nomor 2, Tahun 2021

e-ISSN 2477-6300

Namun tetapa ada beberapa keterbatasan dalam penelitian antara lain, kondisi Covid-19 memaksa peneliti menyebarkan instrumen secara daring dan dikerjakan sendiri. Mungkin akan memberikan hasil yang lebih bermanfaat jika instrumen merupakan hasil pengamatan guru bimbingan dan konseling, pengamatan wali kelas dan hasil kerja peserta didik sendiri. Keterbatasan lainnya penggunaan instrumen penelitian dengan hasil uji ulang reliabilitas jauh lebih rendah diri pada uji reliabilitas studi awal. Penelitian ulang dengan subjek dan instrumen yang lebih baik akan memberikan manfaat lebih untuk perkembangan teori kesiapan karier.

\section{PENUTUP}

Kemampuan perencanaan karier merupakan kompetensi peserta didik untuk dapat mementukan, merencanakan dan memilih pekerjaan yang sesuai dengan dirinya. Motivasi belajar merupakan prediktor dari kemampuan perencanaan karier peserta didik. Motivasi yang muncul dari dalam diri merupakan pendorong yang kuat untuk peserta didik mampu memilih dan mengambil keputuan karier. Layanan konseling karier sangat dibutuhkan tidak hanya peserta didik, namun juga orang tua. Keselarasan persepsi anak dan orang tua merupakan pendorong yang kuat perserta didik memiliki motivasi belajar tinggi. Selanjutnya menggidentifikasi potensi peserta didik untuk memprediksi kemampuan perencanaan karier akan menarik untuk penelitian selanjutnya.

\section{REFERENSI}

Achyanadia, S. (2013). Hubungan Kebiasaan Belajar dan Motivasi Belajar dengan Hasil Belajar IPA Siswa Kelas VII SMP Negeri 1 Ciseeng. Jurnal Teknologi Pendidikan, 2(2). https://doi.org/10.29210/12016263

Aminurrohim, A. W., Saraswati, S., \& Kurniawan, K. (2014). Survei faktor-faktor penghambat perencanaan karier siswa. Indonesian Journal of Guidance and Counseling: Theory and Application, 3(2). https://doi.org/10.15294/IJGC.V3I2.3765

Amsir, J., \& Arifyanto, A. T. (2021). FaktorFaktor Penghambat Perencanaan Karier Siswa. Jurnal Ilmiah Bening: Belajar Bimbingan Dan Konseling, 5(1), 57-66. http://ojs.uho.ac.id/index.php/bening/articl e/view/12107

Anugraheni, A. R., Seprina, C. A., Paramitasari, S. P., \& Kurnia, V. (2019). Skala Motivasi Belajar: Konstruksi dan Analisis
Psikometri. Proceeding of The URECOL, 66-69.

Atmaja, T. T. (2014). Upaya meningkatkan perencanaan karier siswa melalui bimbingan karier dengan penggunaan media modul. Psikopedagogia, 3(2), 5868.

https://core.ac.uk/download/pdf/32420048 4.pdf

Emda, A. (2018). Kedudukan motivasi belajar siswa dalam pembelajaran. Lantanida Journal, $\quad 5(2), \quad$ 172-182. http://103.107.187.25/index.php/lantanida/ article/view/2838

Gusta, A. W. D. (2020). Pengaruh Layanan Perencanaan Individual Terhadap Kesiapan Peserta Didik Dalam Menentukan Sekolah Lanjutan Di Smp Negeri 28 Bandar Lampung Tahun Pelajaran 2019/2020. Skripsi. Universitas Islam Negeri Raden Intan Lampung.

Habibi, A. S. Y. (2021). Kontribusi Persepsi Siswa tentang Jurusan dan Harapan Orangtua terhadap Perencanaan Karier Siswa SMKN 2 Kota Bukittinggi. [Universitas Negeri Padang]. http://repository.unp.ac.id/30713/

Idola, S., Sano, A., \& others. (2017). Hubungan Antara Persepsi Siswa Tentang Keadaan Lingkungan Fisik Sekolah Dengan Motivasi Belajar. Jurnal EDUCATIO: Jurnal Pendidikan Indonesia, 2(2), 30-34. https://doi.org/10.32832/tek.pend.v2i2.447

Komara, I. B. (2016). Hubungan antara kepercayaan diri dengan prestasi belajar dan perencanaan karier siswa. Jurnal Psikopedagogia, 5(1), 33-42. https://d1wqtxts1xzle7.cloudfront.net/5530 9583/4474-9420-1-PB

Massie, R. (2015). Pengaruh perencanaan karier, pelatihan dan Pengembangan karier terhadap kinerja pegawai pada museum negeri provinsi sulawesi utara. Jurnal Berkala Ilmiah Efisiensi, 15(5). https://ejournal.unsrat.ac.id/index.php/jbie/ article/view/10275

Nazirwan, N. (2020). Pemberdayaan Sumber Daya Manusia Studi Kasus pada Madrasah Ibtidaiyah Negeri 1 Kota Jambi. Jurnal Pendidikan Guru, I(2). https://jurnal.literasikitaindonesia.com/inde x.php/jurpendigu/article/view/164

Nugraha, Y. P., Awalya, A., \& Mulawarman, M. (2021). Predicting video game addiction: The effects of composite regulatory focus

Dipublikasikan Oleh :

UPT Publikasi dan Pengelolaan Jurnal

Universitas Islam Kalimantan Muhammad Arsyad Al-Banjari Banjarmasin 
Yurike Kinanthy Karamoy, Endarta Murti Basuki

Jurnal Bimbingan dan Konseling Ar-Rahman

Volume 7, Nomor 2, Tahun 2021

e-ISSN 2477-6300

and interpersonal competence among indonesian teenagers during covid-19 pandemic. Islamic Guidance and Counseling Journal, 4(1), 66-77. https://doi.org/10.25217/igcj.v4i1.1199

Patel, S. G., Salahuddin, N. M., \& O'Brien, K. M. (2008). Career decision-making selfefficacy of Vietnamese adolescents: The role of acculturation, social support, socioeconomic status, and racism. Journal of Career Development, 34(3), 218-240. https://doi.org/10.1177/089484530730848 8

Prahmawati, C. A. (2018). Career Mind Mapping Melalui Teknik Diskusi Kelompok Untuk Meningkatkan Kemampuan. In Universitas Muhammadiyah Malang. http://eprints.umm.ac.id/42716/1/

Rosyadi, I. (2017). Pengaruh Pengalaman On The Job Training dan Motivasi Memasuki Dunia Kerja Terhadap Kesiapan Kerja Siswa. Economic Education Analysis Journal, 6(1), 173-187.

Saptono, Y. J. (2016). Motivasi dan keberhasilan belajar siswa. REGULA FIDEI: Jurnal Pendidikan Agama Kristen, 1(1), 181-204. http://christianeducation.id/ejournal/index.php/regulafidei/article/view/ 9

Sardiman, A. M. (2001). Interaction and Motivation in Teaching and Learning. Grafindo.

Septianti, N., \& Afiani, R. (2020). Pentingnya Memahami Karakteristik Siswa Sekolah Dasar Di SDN Cikokol 2. AS-SABIQUN, 2(1), 7-17. https://doi.org/10.36088/assabiqun.v2i1.61

Siregar, A. S. (2020). Implementasi Program Bimbingan Pribadi Sosial Dalam Mengembangkan Kecerdasan Emosional Siswa di Madrasah Aliyah Laboratorium UIN SU Medan. Universitas Islam Negeri Sumatera Utara Medan.

Sulusyawati, H., \& Melati. (2019). Pengaruh Budaya Rejang Terhadap Perencanaan Karier Siswa Di Sma Negeri 9 Kota Bengkulu. Psikodidaktika: Jurnal Ilmu Pendidikan, Psikologi, Bimbingan Dan Konseling, $\quad 4(2), \quad 27$. https://doi.org/10.32663/psikodidaktika.v4i 2.1016

Supriadi, D. (2019). Pengaruh Motivasi Belajar Terhadap Hasil Belajar Matakuliah Metode Penelitian Mahasiswa Semester Genap Tahun 2018/2019. Educate: Jurnal Teknologi Pendidikan, 4(2), 97-106. http://150.107.142.43/index.php/EDUCAT E/article/view/2175

Suryani, S., Irianto, A., \& Cerya, E. (2019). Pengaruh Motivasi Belajar Dan Praktik Kerja Industri Terhadap Kesiapan Kerja Siswa Kelas XII Smk Bisnis Manajemen Di Kota Solok. Jurnal Ecogen, 1(4), 870. https://doi.org/10.24036/jmpe.v1i4.5666

Susanti, R., \& Mulyoto, M. (2020). Kesiapan Kerja Siswa BLK Ditinjau Dari Kemandirian Belajar, Motivasi Kerja dan Pengalaman On The Job Training. Media Manajemen Pendidikan, 3(1), 1. https://doi.org/10.30738/mmp.v3i1.3424

Syafaruddin, S., Syarqawi, A., \& Siahaan, D. N. A. (2019). Dasar-dasar bimbingan dan konseling: Telaah Konsep, Teori dan Praktik. 